УДК 377.147

С. І. Почтовюк,

кандидат педагогічних наук

(Кременчуцький національний університет імені Михайла Остроградського) svetlanapoctovyukegmail.com ORCID: 0000-0002-0463-0072

\title{
СУТНІСТЬ МЕТОДИЧНОЇ КОМПЕТЕНТНОСТІ ВЧИТЕЛЯ ІНФОРМАТИКИ
}

У статті розглядаються основні питання щздо проблем формування методичної компетентності сучасного вчителя. Представлено структурно-функиіональну схему методичної компетентності вчителя інформатики. Методична компетентність розглядається як інтегративна багаторівнева професійно значуща характеристика особистості вчителя, щуо виражається у наявності ціннісного відношення до педагогічної професії, професійних знань, вмінь та навичок, розглянутих як ијілісна система. Всі компоненти, щчо виокремленні у наведеній структурі необхідно розглядати у взаємозв 'язку, не можливо розкрити суть поняття "методична компетентність", розглядаючи ї̈ лише в одному аспекті.

\section{Ключові слова: методична компетентність, функиї методичної компетентності, компоненти} методичної компетентності, вчитель інформатики.

Перехід в освіті на компетентнісну парадигму робить проблему розвитку методичних компетентностей вчителя особливо актуальною. Аналіз проблеми запровадження та розвитку компетентнісного підходу дає змогу виділити методичну компетентність як одну із складових ключових компетентностей фахівця, та встановити іiі як вимогу для розвитку професійної компетентності, котра означає гнучкість, самоспрямованість навчання, здатність до незалежного вирішення проблем, самовизначення [1].

Проблеми формування методичних компетентностей в педагогічних дослідженнях висвітлюються в роботах В. А. Адольфа, А. О. Вербицького, І. В. Гребенєва, Н. В. Кузьміної та інших. Як складова професійної педагогічної компетентності методична компетентність розглядається в роботах В. А. Адольфа, Н. В. Кузьминої, А. К. Маркової, Л. М. Митіної та інших.

Аналіз науково-методичної та педагогічної літератури свідчить про широкий спектр поглядів учених, педагогів на природу такого феномена, як методична компетентність (Г. О Грищенко, В. Ф. Заболотний, Н. В. Кузьміна, О. М. Ніколаєв, В. О. Ніжегородцев, О. В. Овчарук, Т. В. Сясіна). Але термін "методична компетентність" сьогодні $є$ недостатньо визначеним, не дивлячись на важливу роль власне методичної підготовки учителя в його практичній діяльності взагалі та учителя інформатики зокрема, а також вплив рівня його методичної компетентності на ефективність освітнього процесу.

Метою статті є дослідження сутності поняття методичної компетентності вчителя інформатики, а саме його характеристики, структури та функцій.

Для досягнення поставленої мети вирішувалися наступні завдання:

- провести аналіз філософської, психологічної, педагогічної та ін. літератури 3 проблеми дослідження;

- виокремити основні компоненти методичної компетентності вчителя інформатики;

- розробити структурно-функціональна схему методичної компетентності майбутнього вчителя інформатики.

У ході дослідження були застосовані такі методи:

- загальнонаукові методи: аналіз і синтез, індукція та дедукція;

- методи теоретичного рівня: аналіз наукової, навчальної та методичної літератури 3 питань розуміння понять "методична" та "професійна компетентність", 3 питань професійної підготовки майбутніх вчителів;

методи емпіричного рівня: педагогічне спостереження, бесіди, узагальнення.

Виклад основного матеріалу. Визначальним фактором ефективної практичної діяльності вчителя $€$ його методична компетентність, що охоплює предметні знання, володіння різними методами, прийомами навчання, а також розуміння психолого-педагогічних механізмів засвоєння учнями знань і вмінь. Аналіз проблеми запровадження та розвитку компетентнісного підходу дає змогу виділити методичну компетентність як одну із складових ключових компетентностей фахівця, та встановити іï як вимогу для розвитку професійної компетентності, котра означає гнучкість, самоспрямованість навчання, здатність до незалежного вирішення проблем, самовизначення [1].

Деякі науковці методичну компетентність виокремлюють як вид професійної компетентності (в області способів формування знань, вмінь и навичок тих, хто навчається) та розглядають ії як головну складову їх педагогічної майстерності. Методична компетентність розглядається науковцями в якості одного із основних елементів професійної компетентності педагога і включає в себе компетентність в 
області формування знань, вмінь та навичок в учнів; також під методичною компетентністю розуміють володіння різними методами навчання, знання психологічних механізмів засвоєння знань та вмінь в процесі навчання [2].

Виступаючи як індивідуальний суб'єкт професійної діяльності, вчитель є носієм загальноосвітніх знань та цінностей. Будь-який вид діяльності $є$ похідною від певних якостей особистості. Успішне виконання діяльності потребує: активного позитивного відношення до цієї діяльності, схильності займатися нею, що перетворюється на високому рівні розвитку у захопленість; ряду характерологічних якостей (працелюбності, організованості, самостійності, наполегливості тощо), а також стійких інтелектуальних вмінь; наявності під час діяльності сприятливих для їі виконання психічних станів (зосередженості, зацікавленості тощо); визначення фонду знань, вмінь та навичок у відповідній галузі; визначення індивідуально психологічних особливостей у розумових та сенсорних сферах, що відповідають вимогам певної діяльності. Тому стосовно розгляду загальної характеристики особистості вчителя необхідно цілісне поєднання афективної, когнітивної та діяльнісної сфер. При цьому друга має бути розглянута у двох аспектах: загальнокультурні знання та предметно-професійні (психологопедагогічні, предметні, методичні). Вчитель завжди має бути особистістю з наявними індивідуальнопсихологічними, поведінковими та комунікативними якостями.

Методична компетентність виступає як інтегрована особистісно професійна характеристика вчителя, що потребує багатоаспектного підходу до вивчення цього поняття. Як система, вона включає в себе гуманістичну направленість, мотиви, цілі, ціннісні орієнтири, вимагає сукупності знань, вмінь, форм та способів їх використання в умовах освітнього процесу, що постійно змінюються. Стосовно вчителя інформатики, під методичною компетентністю ми розуміємо інтегративну багаторівневу професійно значущу характеристику його особистості, що виражається у наявності ціннісного відношення до педагогічної професії, професійних знань, вмінь та навичок, розглянутих як цілісна система.

Основу афективного компонента методичної компетентності вчителя інформатики складає його особиста позиція як носія професійних цінностей; когнітивний компонент вказує на володіння професійними знаннями (предметні, психолого-педагогічні, методичні); діяльнісний компонент відповідає ступені готовності майбутнього вчителя до відносин у освітньому процесі.

Отже, структуру методичної компетентності вчителя інформатики може бути подана у вигляді схеми.

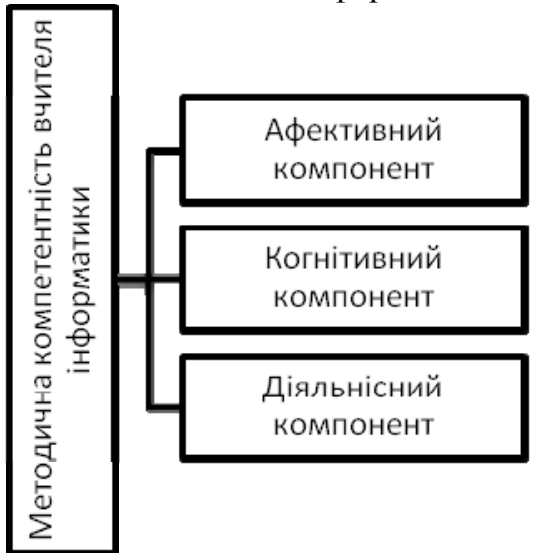

Рисунок 1. Структура методичної компетентності вчителя інформатики

Після того як виведено поняття методичної компетентності вчителя, необхідно визначити сутність даного феномену. У словнику української мови сутність - найголовніше, основне, істотне в кому-, чомунебудь; суть, зміст [3: 860]. Сутність речей трактується як дещо незалежне, абсолютне (Платон, Гегель). Сутність є створення суб’єкта, що проецирує сутність поза собою та уявляє іiі у вигляді речей. Сутність має місце не поза речами, а в них й через них, як загальна головна властивість, як їх закон. Сутність сукупність глибинних зв'язків, відношень й внутрішніх законів, що визначають основні характеристики і тенденції розвитку матеріальної системи.

У сучасній філософії категорія "сутність" досить часто витісняється поняттями "значення", "смисл", "структура". Сутність - категорія онтології на позначення внутрішнього, сукупність істотних властивостей предмета, без яких він існувати не може; головне, визначальне в предметі, що зумовлене глибинними зв'язками й тенденціями розвитку і пізнається на рівні теоретичного мислення [4: 623].

У філософському розумінні "значення і смисл" - характеристики знаку, які фіксують, з одного боку, те, представником чого знак $\epsilon$, що він іменує, виокремлює, позначає, а 3 другого - спосіб, яким знак позначає предмет; характеристику позначуваних предметів (виражену в самій структурі знака - власний смисл. Смисл однозначно визначає значення (якщо останнє взагалі наявне) [4: 229].

Сутність поняття методичної компетентності реалізується через його функції. Функція (лат. function виконання, створення) розуміється як зовнішній прояв властивостей об'єкту в системі відношень; 
діяльність, здатність до діяльності, значення, властивість, роль, задача, залежність однієї величини від іншої, спосіб прояву активності, життєдіяльності системи та їі компонентів; форму поведінки, що здатна зберігати компоненти та систему в цілому, взаємозв'язок, що визначає порядок включення компонентів, частин тощо [5: 504].

Функції методичної компетентності - це способи прояву активності особистості вчителя при виконанні ним навчання та виховання учнів. Для виявлення функцій методичної компетентності було розглянуто функції близьких, на наш погляд, за значенням понять: "професійна компетентність", "педагогічна компетентність", "професійна компетентність керівника", "готовність до професійного спілкування", "комунікативна компетентність" (А. А. Бабенко, В.В.Горшкова, О.І.Гура, І. О. Зимня, Н. В. Кузьміна та ін.) та виділено функції методичної компетентності вчителя інформатики, що, на наш погляд, необхідні для визначення сутності досліджуваної компетентності.

Мотиваційна функція виявляється у розвитку у вчителя позитивного відношення до педагогічної діяльності, що виражене через його гуманістичну направленість, прагнення до реалізації творчого потенціалу.

Ціннісна функція виявляється у ціннісному відношенні до професії вчителя.

Гностична функція забезпечує активізацію пізнавальної, інтелектуальної діяльності вчителя, володіння їм знаннями, що необхідні для виконання професійно-педагогічної діяльності.

Комунікативна функція пов'язана із взаємодією суб'єктів та об’єктів освітнього процесу та виявляється у відкритості до спілкування, вмінні чітко висловлювати думки, аргументовано їх доводити, переконувати, передавати раціональну та емоційну інформацію, організовувати та підтримувати діалог.

Рефлексивна функція виявляється в усвідомленні вчителем свого власного професійного образу, у цілісному оцінюванні самого себе як професіонала.

Отже, методична компетентність майбутнього вчителя інформатики нами розглядається як поєднання трьох компонентів, а саме: афективного, когнітивного, діяльнісного.

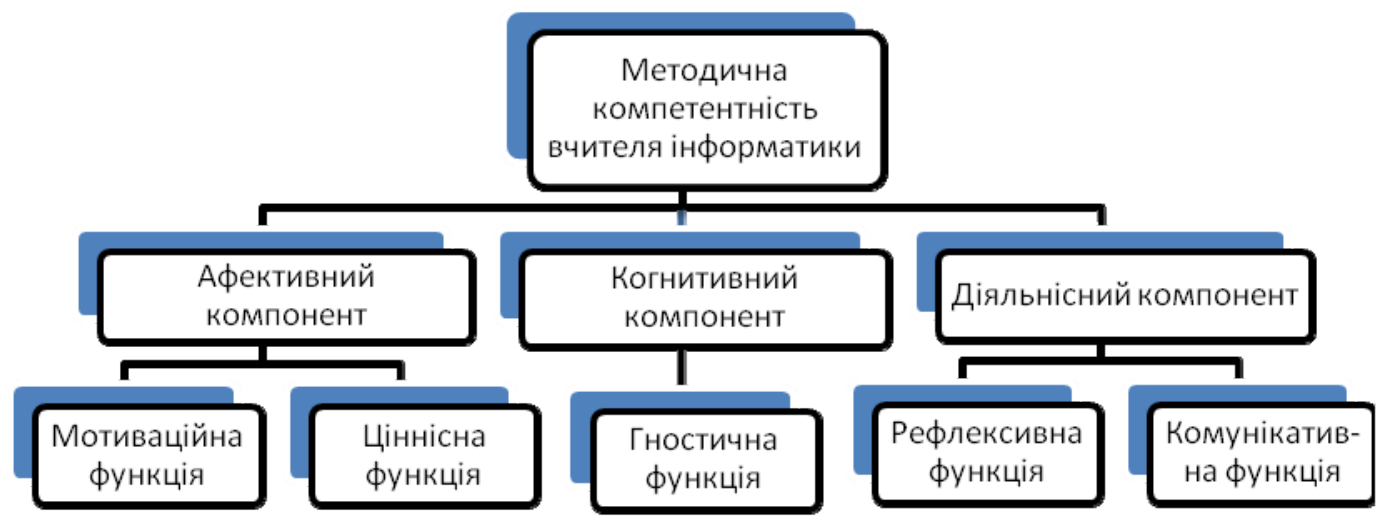

Рисунок 2. Структурно-функціональна схема методичної компетентності майбутнього вчителя інформатики

Розвиток афективного компонента сприяє реалізації мотиваційної та ціннісної функцій; розвиток когнітивного компонента направлено на реалізацію гностичної функції; розвиток діяльнісного компонента сприяє реалізації комунікативної та рефлексивної функцій.

Афективний компонент містить мотивації формування методичної компетентності, професійні цінності, стимулює творчі прояви особистості у професійної діяльності. В основу даного компонента нами покладено наявність гуманістичної направленості особистості майбутнього вчителя, прагнення до творчої самореалізації, ціннісне відношення до професії вчителя. Мотив формування методичної компетентності розглядається як детермінанти активності особистості у процесі спільної навчальнопедагогічної діяльності.

Когнітивний компонент розглядається нами як сукупність психолого-педагогічних, предметних i методичних знань, знань про професійну діяльність, а також про взаємодії суб'єктів під час цієї діяльності. Основу даного компоненту складає знання основних педагогічних технологій, психологічних особливостей школярів, вільне володіння змістом шкільного курсу інформатики та методиками навчання, знання про сутність методичної компетентності.

Основу діяльнісного компонента складають вміння педагога, що відповідають елементам педагогічної діяльності: гностичному, проектувальному, конструктивному, комунікативному та організаторському [2].

Поняття "рефлексивності" сьогодні розглядається як одна з характеристик свідомості особистості [6]. В психології існують кілька означень рефлексії, що формулюються в контексті проблематики тієї або 
іншої галузі. Рефлексія "повертає" свідомість людини на іï внутрішній світ. Це допомагає не тільки усвідомити свої вчинки, стосунки, цінності, але при необхідності, їх перебудувати, знайти нові.

Рефлексія - це не тільки саморозуміння, самопізнання, а й як одна із значущих характеристик професійного спілкування. В процесі безпосереднього спілкування (наприклад, при груповій дискусії на заняттях) включається також і комунікативна рефлексія. Рефлексивність проявляється в умінні свідомо контролювати результати своєї власної діяльності та рівень сформованості професійно значущих для вчителя характеристик та властивостей, таких як активність, індивідуальність, креативність, а також психолого-педагогічних, предметних та методичних знань та вмінь.

Будь-яка характеристика особистості формується та проявляється під час іiі діяльності. Методична компетентність вчителя проявляється у трьох аспектах його професійно-педагогічної діяльності: викладання предмета, організація позашкільної роботи з предмету, класне керівництво. Наведена вище структурно-функціональна схема буде відповідати кожному з названих аспектів.

Враховуючи вище зазначене виділимо зміст методичної компетентності вчителя інформатики, що забезпечує планування та конструювання уроку, а саме:

- визначення обсягу матеріалу, виділення узагальнених понять, законів, принципів, світоглядних ідей, провідних наукових теорій, моральних та естетичних ідеалів, методів дослідження та наукового мислення; аналіз пізнавальних завдань, що спрямовані на засвоєння знань та інтелектуальний розвиток учнів;

- моделювання процесу реалізації основних етапів уроку з інформатики, компактне "відтворення" тих мисленнєвих і практичних операцій, які колись здійснювались у процесі наукового дослідження (пізнання) явищ або предметів. Успіх всього освітнього процесу значною мірою залежить від того, які методи навчання застосовуються. Вчитель має розуміти суть різних підходів до класифікації методів, але найперше - мати у своєму арсеналі велику кількість цих методів, аби вдало й ефективно використовувати їх в освітньому процесі залежно від дидактичної мети і функціональної спрямованості навчання;

- організація цілеспрямованого управління навчальною діяльністю учнів, здійснення контролю за якістю оволодіння навчальним матеріалом і спонуканням учнів до самоконтролю. Контроль та самоконтроль забезпечують функціонування зворотного зв'язку у навчальному процесі - одержання вчителем даних про ступінь труднощів, типові недоліки на кожній стадії навчання. Управляючий вплив здійснюється зі зворотнім зв'язком і відбувається на основі відомостей про здобуті результати, при цьому управління передбачає обов'язкове вивчення рівня засвоєння знань, умінь та навичок, їх порівняння $з$ попередньо визначеними характеристиками, виявлення відмінностей між ними, здійснення необхідного коригування.

Висновки. Отже, нами виявлена сутність та структура поняття "методична компетентність" як інтегрована характеристика особистості вчителя. Всі компоненти, що виокремленні у структурі методичної компетентності вчителя інформатики, знаходяться у взаємозв'язку, не можливо розкрити суть поняття "методична компетентність", розглядаючи іiі лише в одному аспекті. Становлення кожного компоненту пов'язано з формуванням його характеристик та властивостей як частин цілісної системи.

Подальших досліджень потребує розгляд формування феномену методичної компетентності майбутнього вчителя інформатики стосовно кожного з зазначених аспектів.

\section{СПИСОК ВИКОРИСТАНИХ ДЖЕРЕЛ ТА ЛІТЕРАТУРИ}

1. Раков С. А. Математична освіта : компетентнісний підхід з використанням IКТ : [монографія] / С. А. Раков. - Х. : Факт, 2005. - 360 с.

2. Кузьмина Н. В. Профессионализм личности преподавателя / Н. В. Кузьмина. - М. : АПН. - 1990. -149 с.

3. Білодід І. К. Словник української мови : в 11 т / І. К. Білодід. - К. : Наукова думка, 1970. - Т. 9. - 920 с.

4. Шинкарук В. І. Філософський енциклопедичний словник / В. І. Шинкарук. - НАН України, Ін-т філософії імені Г. С. Сковороди. - Київ : Абрис, 2002. - 742 с.

5. Фролов И. Т. Философский словар / И. Т. Фролов. - М. : Политиздат, 1991. - 560 с.

6. Рубинштейн С. Л. Основы общей психологии / С. Л. Рубинштейн. - СПб. : Издательство Питер, 2007. $720 \mathrm{c}$.

\section{REFERENCES (TRANSLATED \& TRANSLITERATED)}

1. Rakov S. A. Matematychna osvita : kompetentnisnyi pidkhid z vykorystannyam IKT [Mathematical Education : a Competency Approach Using ICT] / S. A. Rakov. - X. : Fakt, 2005. - 306 s.

2. Kuz'mina N.V. Professionalizm lichnosti prepodavatelia [Professionalism of the Teacher's Personality]/ N. V. Kuz'mina. - M. : APN. - 1990. - 149 s.

3. Bilodid I. K. Slovnyk ukraiunskoiu movi [Dictionary of the Ukrainian Language] / I. K. Bilodid. - Kyiv : Naukova dumka, 1970. - T 8.

4. Shynkaruk V. I. -Ed... -2002.. Filosofs'kyi entsyklopedychnyi slovnyk [Philosophical Encyclopedic Dictionary]/ V. I. Shynkaruk. - Kyiv : Abrys [in Ukrainian].

5. Frolov I. T. Filosofskii slovnyk [Philosophical Dictionary] / I. T. Frolov. - M. : Politizdat, 1991. $-560 \mathrm{~s}$. 
6. Rubynshtein S. L. Osnovy obshchei psikhologii [Fundamentals of General Psychology] / S. L. Rubynshtein. - M. : Pedahohika, 2007. $-720 \mathrm{~s}$.

\section{Почтовюк С. И. Сущность методической компетентности учителя информатики.}

В статье рассматриваются основные вопросы проблемы формирования методической компетентности современного учителя. Представлена структурно-функциональная схема методической компетентности учителя информатики. Методическая компетентность рассматривается как интегративная многоуровневая профессионально значимая характеристика личности учителя, выражается в наличии ценностного отношения к педагогической профессии, профессиональных знаний, умений и навыков, рассмотренных как иелостная система. Все компоненты, выделенные в приведенной структуре необходимо рассматривать во взаимосвязи, невозможно раскрыть суть понятия "методическая компетентность", рассматривая ее лишь в одном аспекте.

Ключевые слова: методическая компетентность, функиии методической компетентности, компоненты методической компетентности, учитель информатики.

\section{Pochtovyuk S. I. Essence of Methodical Competence of Computer Sciences Teacher.}

The change to the competence paradigm in education makes the problem of teachers' methodical competences development particularly relevant. The analysis of the problem of implementation and development of the competence approach allows to identify the methodological competence as one of the components of the key competencies of the specialist, as well as to establish it as a requirement for the development of professional competence.

The analysis of scientific-methodical and pedagogical literature testifies to a wide range of views of scientists and teachers on the essence of such concept as methodical competence. Despite the important role of methodological training of teachers in their practice and the impact of the level of their methodological competence on the effectiveness of the educational process, the term "methodological competence" today is not enough defined.

The purpose of the article is to study the essence of the concept of methodical competence of a computer science teacher, particularly its characteristics, structure and functions. In the course of the research the following methods were used: general scientific methods (analysis and synthesis, induction and deduction), methods of theoretical level (analysis of scientific, educational and methodical literature on the understanding of the concepts of "methodical" and "professional competence"); methods of empirical level (pedagogical observation, conversations, generalization).

Methodical competence acts as an integrated personal professional characteristic of the teacher, requiring a multidimensional approach to the study of this concept.

The essence of the concept of methodical competence is realized through its functions. Methodical competence of the prospective computer science teacher is considered by us as a combination of three components, namely: affective, cognitive, activity. The development of the affective component contributes to the implementation of motivational and value functions; the development of the cognitive component is aimed at the implementation of the gnostic function; the development of the activity component contributes to the implementation of communicative and reflexive functions.

Consequently, the formation of each component is associated with the formation of its characteristics and properties as part of an integrated system.

Key words: methodical competence, functions of methodical competences, components of methodical competence, computer science teacher. 